\title{
The effect of melt-spun phase change material fibre garments on skin temperature in humans
}

\author{
Maria Suong Tjønnås*, Hilde Færevik, Mariann Sandsund, Randi E Reinertsen \\ From 15th International Conference on Environmental Ergonomics (ICEE XV) \\ Portsmouth, UK. 28 June - 3 July 2015
}

\begin{abstract}
Introduction
Phase change materials (PCM) have the ability to store latent heat, a property that is utilized in the making of thermo regulating clothing [1]. The melt-spun PCM fibre [2] has a polyester sheath and PCM filled core, giving the fibre its cooling properties. By virtue of being a fibre, it enables production of a knitted fabric with high air and moisture permeability as well as high flexibility qualities. The flexible knitted fabric allows for betterfitting clothes [3], and larger area of the body surface to be covered and exposed to the cooling effects of the melt-spun PCM fibre. The aim of this study was to investigate the effects of a melt-spun PCM fibre sweater with PCM melting temperature at $28.4{ }^{\circ} \mathrm{C}$ and crystallisation temperature at $25.2{ }^{\circ} \mathrm{C}$, on the skin temperatures of the upper body and perceived thermal sensation and comfort in a hot environment.
\end{abstract}

\section{Methods}

Fourteen test subjects ( 8 male, 6 female; mean (SD) age 23 (3) y; height $171(11) \mathrm{cm}$; weight $65.3(8) \mathrm{kg}$ ) completed a passive heat session (rested on a chair in a climatic chamber at $30{ }^{\circ} \mathrm{C}$ and $50 \%$ rh). Skin thermistors were placed on 4 different locations, the upper arm, chest, scapula and lower back to measure the average skin temperature of the upper body. When the skin temperatures were stabilised, the cooling PCM fibre sweater (estimated PCM mass; 28 (g), specific latent heat capacity; $1.842(\mathrm{~kJ}))$ was put on in an ambient temperature of $30.5(0.5){ }^{\circ} \mathrm{C}$ to ensure that the PCM would be in a liquid phase. The test subjects sat for 20 minutes further in the climatic chamber. The perceived thermal sensation and comfort was rated by each test subject at particular points during the test course. The same

* Correspondence: MariaSuong.Tjonnas@sintef.no

SINTEF Technology and Society, department of Health Research, Trondheim, Norway 


\section{References}

1. Mondal S: Phase Change Materials for Smart Textiles - An Overview. Applied Thermal Engineering 2008, 28(11):1536-1550.

2. NoTeReFiGa. [http://extra.ivf.se/noterefiga], project NMP2-SE-203831-2.

3. Stegmaier T, Mavely J, Schneider P: 6 - High-Performance and HighFunctional Fibres and Textiles. In In Textiles in Sport. Cambridge: Woodhead publishing:R. Shishoo 2005:89-119.

4. Tjønnås MS, Færevik $H$, Sandsund M, Reinertsen RE: The dry-heat loss effect of melt-spun phase change material fibres. Ergonomics 2014, 58(3), 2015 .

doi:10.1186/2046-7648-4-S1-A75

Cite this article as: Tjønnås et al.: The effect of melt-spun phase change material fibre garments on skin temperature in humans. Extreme

Physiology \& Medicine 2015 4(Suppl 1):A75.

Submit your next manuscript to BioMed Central and take full advantage of:

- Convenient online submission

- Thorough peer review

- No space constraints or color figure charges

- Immediate publication on acceptance

- Inclusion in PubMed, CAS, Scopus and Google Scholar

- Research which is freely available for redistribution

Submit your manuscript at www.biomedcentral.com/submit 